\title{
Trends in the epidemiology of young-onset colorectal cancer: a worldwide systematic review
}

Khalid Saad El Din ${ }^{1,2}$, Jonathan M. Loree ${ }^{3,4}$, Eric C. Sayre ${ }^{5}$, Sharlene Gill ${ }^{3,4}$, Carl J. Brown ${ }^{6,7}$, Hallie Dau ${ }^{1,2}$ and Mary A. De Vera ${ }^{1,2,5^{*}}$

\begin{abstract}
Background: Recent data suggest that the risk of young-onset colorectal cancer (yCRC), in adults less than 50 years of age, is increasing. To confirm findings and identify contemporary trends worldwide, we conducted a systematic review of studies examining population-level trends in yCRC epidemiology.

Methods: We searched MEDLINE (1946-2018), EMBASE (1974-2018), CINAHL (1982-2018), and Cochrane Database of Systematic Reviews (2005-2018) for studies that used an epidemiologic design, assessed trends in yCRC incidence or prevalence, and published in English. Extracted information included country, age cut-off for yCRC, and reported trends in incidence or prevalence (e.g. annual percent change [APC]). We pooled similarly reported trend estimates using random effects models.

Results: Our search yielded 8695 articles and after applying our inclusion criteria, we identified 40 studies from 12 countries across five continents. One study assessed yCRC prevalence trends reporting an APCp of +2.6 and +1.8 among 20-39 and 40-49 year olds, respectively. 39 studies assessed trends in yCRC incidence but with substantial variability in reporting. Meta-analysis of the most commonly reported trend estimate yielded a pooled overall APCi of $+1.33(95 \% \mathrm{Cl}, 0.97$ to $1.68 ; p<0.0001)$ that is largely driven by findings from North America and Australia. Also contributing to these trends is the increasing risk of rectal cancer as among 14 studies assessing cancer site, nine showed an increased risk of rectal cancer in adults less than 50 years with APCi up to $+4.03(p<0.001)$.
\end{abstract}

Conclusions: Our systematic review highlights increasing yCRC risk in North America and Australia driven by rising rectal cancers in younger adults over the past two decades.

Keywords: Young-adult cancer, Epidemiology, Incidence, Meta-analysis, Cancer

\section{Background}

Colorectal cancer $(\mathrm{CRC})$ is a heterogeneous disease of the colon and rectum predominantly arising from adenomatous polyps or adenomas [1]. The International Agency for Research on Cancer estimated 1.36 million

\footnotetext{
* Correspondence: mdevera@mail.ubc.ca

'Faculty of Pharmaceutical Sciences, University of British Columbia, 2405 Wesbrook Mall, Vancouver, BC Canada V6T 1Z3, Canada

${ }^{2}$ Collaboration for Outcomes Research and Evaluation, 2405 Wesbrook Mall, Vancouver, BC Canada V6T 1Z3, Canada

Full list of author information is available at the end of the article
}

new cases of CRC in 2012 making it the third most common cancer in the world [2].

While CRC has long been considered a disease of older adults [3], recent data suggest an increasing incidence of young-onset CRC (yCRC), which has largely been defined as adults younger than 50 years of age [3-7]. In 2018, the American Cancer Society lowered the recommended age for average-risk adults to initiate screening from 50 to 45 years [8]. In 2019, Liu et al. extracted cancer incidence data from the International Agency for

(c) The Author(s). 2020 Open Access This article is licensed under a Creative Commons Attribution 4.0 International License, which permits use, sharing, adaptation, distribution and reproduction in any medium or format, as long as you give appropriate credit to the original author(s) and the source, provide a link to the Creative Commons licence, and indicate if changes were made. The images or other third party material in this article are included in the article's Creative Commons licence, unless indicated otherwise in a credit line to the material. If material is not included in the article's Creative Commons licence and your intended use is not permitted by statutory regulation or exceeds the permitted use, you will need to obtain permission directly from the copyright holder. To view a copy of this licence, visit http://creativecommons.org/licenses/by/4.0/ The Creative Commons Public Domain Dedication waiver (http://creativecommons.org/publicdomain/zero/1.0/) applies to the data made available in this article, unless otherwise stated in a credit line to the data. 
Research on Cancer (IARC) and reported significant increased risk of yCRC for 11 out of 12 countries, with annual percent change in incidence (APCi) ranging from 0.32 ( $95 \%$ confidence interval [CI], 0.01 to 0.64 ) in Italy to 9.20 ( $95 \% \mathrm{CI}, 6.85$ to 11.59 ) in Brazil [9]. Identifying whether these incidence trends for yCRC are also reported in peer-reviewed literature is warranted along with examining prevalence trends in order to inform survivorship support and long-term impacts of yCRC. Our objective was to conduct a systematic review of peer-reviewed, observational studies assessing temporal trends in the incidence (risk) and prevalence (burden) of yCRC.

\section{Methods}

\section{Search strategy}

An information scientist searched Medline (1946-), Embase (1974-), and Cochrane Database of Systematic Reviews (2005-) on the Ovid platform, and CINAHL (1982-) and PsycINFO (1880-) on Ebscohost. Database searches were conducted on January 17, 2018, and then updated on December 3, 2018. To ensure comprehensive capture of both articles that may assess CRC with sub-group reporting allowing extrapolation of yCRC and those that specifically assessed yCRC, we combined two separate but complementary searches. First, we used a broad search strategy with concepts of "colorectal cancer", "prevalence", and "incidence" to identify articles on CRC across all ages from which data could be extracted for individuals with yCRC. Second, we used a specific strategy where we additionally incorporated concepts of "young age" and "early" to identify articles that specifically examined yCRC. We used both database dependent subject headings (e.g. Medical Subject Headings in Medline) and keywords (Supplementary Table 1). We additionally conducted a hand search of the reference lists of the included studies. The protocol is registered with the PROSPERO international prospective register of systematic reviews (ID: CRD42018082151). The Preferred Reporting Items for Systematic Reviews and Meta-Analysis (PRISMA) was applied to our reporting.

\section{Study selection}

We used the following inclusion criteria: 1) original study using epidemiologic design; 2) published in a peerreviewed journal as a full-length article or letter; 3) patient population with $\mathrm{CRC}$ or $\mathrm{yCRC}$; 4) published in English; and 5) assessed trends in the incidence and/or prevalence yCRC, using regression methods (e.g., joinpoint regression, Poisson regression) and reported corresponding estimates (e.g., annual percent change, rate of change of incidence rate). While yCRC has been largely defined in individuals under 50 years [3-7], this may not be the cut-off used in studies and thus, we considered any cut-off for yCRC. We did not consider grey literature such as annual reports from cancer societies as, in our experience, they may not routinely report on yCRC.

\section{Data extraction, quality assessment, and meta-analysis}

We extracted information on country, data source, sample size, sex distribution, age cut-off for yCRC, and cancer site (e.g. colon, rectum). The primary outcome was measures of trends in the incidence (e.g. $\mathrm{APCi}$ ) and prevalence (e.g. APCp) of yCRC. As we noted substantial variability in the reporting of trends during data extraction, we contacted authors to request specific estimates (e.g. overall APC) to facilitate pooling. Where available from the included studies, we also extracted reported incidence rates. As some of the studies meeting inclusion criteria additionally reported on outcomes such as yCRC mortality and/or survival, we considered these as secondary outcomes and extracted relevant information. Two researchers (KS and MDV) independently screened titles and abstracts, reviewed manuscripts, and extracted data, resolving any discrepancies by consensus.

We assessed the quality of included studies with a checklist adapted for this systematic review based on the Joanna Briggs Institute Prevalence Critical Appraisal Tool, developed to address the lack of critical appraisal tools for systematic reviews of studies reporting prevalence [10], and the Appraisal tool for Cross-Sectional Studies, developed to address study design, reporting quality and risk of bias in epidemiologic studies of disease prevalence [11]. We selected relevant criteria from each to create a checklist involving 20 items, with each item scored as 1 ("demonstrated in the study") or 0 ("not demonstrated in study" or "unclear") (Supplementary Table 2). Item scores were summed with higher scores indicating studies of higher quality.

To synthesize findings on trends in yCRC epidemiology across included studies, we pooled the most commonly reported estimate, in particular, the APCi. We applied methods described by Sheu et al. for metaanalysis using linear mixed method [12] and fit random effects models that assigned within-study variances based on standard errors of APC estimates, with between-study variance estimated by restricted maximum likelihood. It should be noted that none of the included studies reported a standard error with the APCi, however, these were derived using reverse Z-tests on either the reported confidence intervals or, if none were provided, the reported $p$-values. When a p-value was reported only as $<\mathrm{X}$ (e.g., < 0.01 ), we based our computation of the standard error on the conservative assumption that $p=\mathrm{X}$. The intercept-only fixed effects solution represents the synthesized common APCi within the group of studies. We obtained pooled 
estimates of APCi and corresponding 95\% confidence intervals $(\mathrm{CI})$ and $p$-values across included studies. We pooled overall APCi and sex-specific APCi, given that studies varied in reporting. We also pooled APCi according to continent. Primarily analysis considered all studies that reported APCi. We also conducted various sensitivity analyses to account for potential overlap between included studies from the United States of America (USA) that used Surveillance, Epidemiology, and End Results Program (SEER) data (e.g., SEER 9, SEER 13). For each group of studies pooled, we computed the Cochran's Q-test and the I-squared statistic to measure the presence of, and degree of heterogeneity [13]. All analyses were performed using SAS v9.4 (SAS Institute, Cary, North Carolina).

\section{Results}

The combined search strategies yielded 8695 (6612 with the broad search strategy and 2083 with the specific search strategy) titles (Fig. 1 provides a PRISMA flow diagram). After applying our inclusion criteria, we identified 40 studies -39 reported trends in yCRC incidence and one in yCRC prevalence. Table 1 summarizes characteristics and quality assessment scores of included studies, according to continent.

\section{Trends yCRC prevalence}

A 2012 Canadian study by Ellison et al. evaluating trends in the prevalence of various cancers reported APCps of yCRC of $+2.6(p<0.01)$ among $20-39$ year-olds and + $1.8(p<0.01)$ among 40-49 year-olds, suggesting an increasing burden over the study period of 2002 to 2008 [20].

\section{Trends in yCRC incidence}

Trends in the incidence of yCRC were reported in 39 studies, with 31 published after 2010 including seven published in the past year (2018) alone [29-33, 40, 46]. Altogether, 31 studies defined yCRC based on a cut-off of diagnosis below the age of 50 years, two based on 40 years [18, 34], three based on 45 years $[15,16,47]$, and three based on 55 years [14, 33, 39]. Incidence rates for yCRC were reported in 17 studies [14, 15, 17, 18, 21, 28, 29, 31, 32, 35-38, 40, 42, 48] (Supplementary Table 3). We estimated a pooled incidence rate per 100,000 for yCRC of 8.0 (95\% confidence interval [CI], 5.8 to 10.3) from seven studies reporting overall rates similarly (e.g. no additional sub-groups such as age) from 1982 to 2014 [17, 21, 30, 32, 35, 37, 48] (Supplementary Figure 1). We estimated pooled incidence rates per 100,000 for yCRC of 6.4 (95\% CI, 4.0 to 8.7) among women (Supplementary Figure 2) and 6.8 (95\% CI, 3.6 to 10.1) among

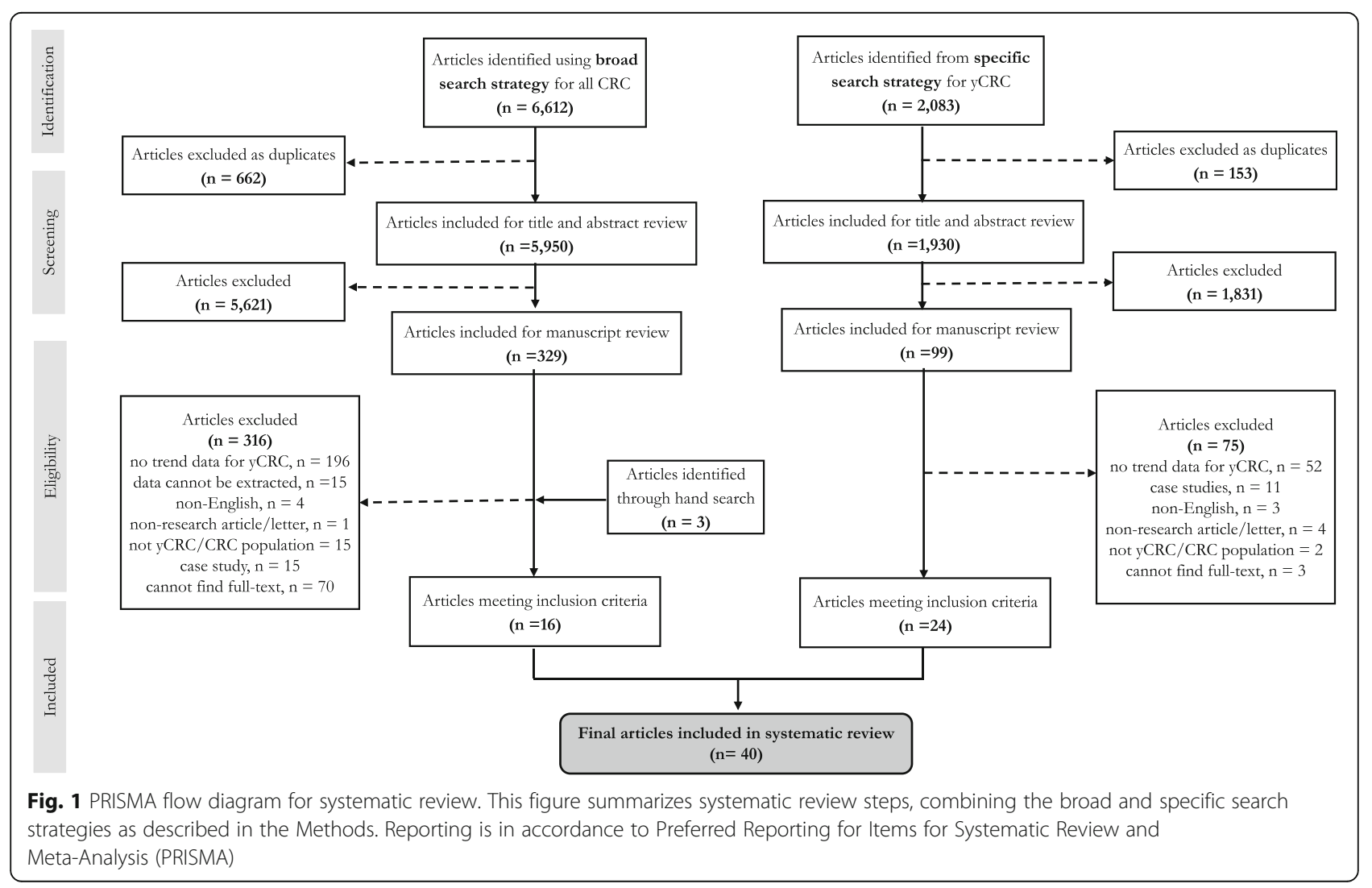


Table 1 Characteristics of included studies according to continent/region

\begin{tabular}{|c|c|c|c|c|c|c|c|c|c|c|}
\hline \multirow[t]{2}{*}{ Study } & \multirow[t]{2}{*}{ Country } & \multirow[t]{2}{*}{ Population /Data Source } & \multicolumn{3}{|c|}{ Cancer Information } & \multirow{2}{*}{$\begin{array}{l}\text { yCRC } \\
\text { age } \\
\text { range } \\
\text { (yr) }\end{array}$} & \multirow{2}{*}{$\begin{array}{l}\mathrm{N}(\mathrm{yCRC} \\
\text { cases) }\end{array}$} & \multicolumn{2}{|l|}{ Outcomes } & \multirow{2}{*}{$\begin{array}{l}\text { Quality } \\
\text { Score }\end{array}$} \\
\hline & & & Site & Definition & Stage & & & $\begin{array}{l}\text { Primary/ } \\
\text { Secondary }\end{array}$ & $\begin{array}{l}\text { Incidence/ } \\
\text { Prevalence } \\
\text { Trend }\end{array}$ & \\
\hline \multicolumn{11}{|c|}{ North America ( $n=26$ studies) } \\
\hline $\begin{array}{l}\text { Chow, } 1991 \\
{[14]}\end{array}$ & USA & SEER-9 & colon & $\mathrm{ICD}-\mathrm{O}$ & not reported & $<55$ & $\begin{array}{l}\text { not } \\
\text { reported }\end{array}$ & incidence & $\begin{array}{l}\text { AAPC } x \operatorname{sex} x \\
\text { ethnicity }\end{array}$ & 18 \\
\hline $\begin{array}{l}\text { Polednak, } \\
1994[15]\end{array}$ & USA & Connecticut Tumor Registry & colorectal & ICD-O & not reported & $\begin{array}{l}0 \text { to } \\
44\end{array}$ & $\begin{array}{l}\text { not } \\
\text { reported }\end{array}$ & incidence & $\begin{array}{l}\% \text { change in } \\
\text { ASR } x \text { sex }\end{array}$ & 18 \\
\hline $\begin{array}{l}\text { Marrett, } \\
2002[16]\end{array}$ & Canada & $\begin{array}{l}\text { National Cancer Incidence } \\
\text { Reporting System, CCR }\end{array}$ & colorectal & ICD-9 & not reported & $\begin{array}{l}20 \text { to } \\
44\end{array}$ & $\begin{array}{l}\text { w: } 2692 \\
\text { m: } 2876\end{array}$ & incidence & AAPC $x$ sex & 18 \\
\hline $\begin{array}{l}\text { Cress, } 2006 \\
{[17]}\end{array}$ & USA & SEER-13 & $\begin{array}{l}\text { colorectal, } \\
\text { rectum }\end{array}$ & ICD-O-3 & $\begin{array}{l}\text { in situ, invasive, } \\
\text { localized, } \\
\text { regional/distant }\end{array}$ & $\begin{array}{l}0 \text { to } \\
49\end{array}$ & $\begin{array}{l}\text { w: } 6893 \\
\text { m: } 7803\end{array}$ & incidence & $\begin{array}{l}\text { 1. } A P C x \operatorname{sex} \\
\text { 2. } A P C x \operatorname{sex} x \\
\text { site }\end{array}$ & 17 \\
\hline $\begin{array}{l}\text { Siegel, } 2009 \\
{[4]}\end{array}$ & USA & SEER-13 & colorectal & ICD-O-3 & $\begin{array}{l}\text { local, regional, } \\
\text { distal }\end{array}$ & $\begin{array}{l}20 \text { to } \\
49\end{array}$ & $\begin{array}{l}\text { w: } 9733 \\
\text { m: } 10 \\
913\end{array}$ & incidence & APC $x$ sex & 16 \\
\hline $\begin{array}{l}\text { Meyer, } 2010 \\
{[18]}\end{array}$ & USA & SEER-9 & $\begin{array}{l}\text { colon, } \\
\text { rectum }\end{array}$ & $\begin{array}{l}\text { not } \\
\text { reported }\end{array}$ & not reported & $\begin{array}{l}<20 \\
\text { to } 39\end{array}$ & $\begin{array}{l}\text { w: } 3662 \\
\text { m: } 3999\end{array}$ & incidence & $\begin{array}{l}\text { 1. } A P C \times \text { site } \\
\text { 2. } A P C \times \text { sex } x \\
\text { site }\end{array}$ & 17 \\
\hline $\begin{array}{l}\text { Merrill, } 2011 \\
\text { [19] }\end{array}$ & USA & SEER-9 & colorectal & ICD-O-2 & not reported & $\begin{array}{l}30 \text { to } \\
49\end{array}$ & $\begin{array}{l}\text { not } \\
\text { reported }\end{array}$ & incidence & $\begin{array}{l}\text { \% change in } \\
\text { RAIR } x \text { sex } x \\
\text { ethnicity }\end{array}$ & 16 \\
\hline $\begin{array}{l}\text { Ellison, } \\
2012[20]\end{array}$ & Canada & $C C R$ & $\begin{array}{l}\text { colon, } \\
\text { rectum }\end{array}$ & ICD-O-3 & not reported & $\begin{array}{l}20 \text { to } \\
49\end{array}$ & $\begin{array}{l}\text { not } \\
\text { reported }\end{array}$ & prevalence & APC $\times$ age & 16 \\
\hline $\begin{array}{l}\text { Giddings, } \\
2012[21]\end{array}$ & USA & California Cancer Registry & colorectal & ICD-O-3 & $\begin{array}{l}\text { localized, regional, } \\
\text { distant }\end{array}$ & $<50$ & $\begin{array}{l}\text { w: } 1278 \\
\text { m: } 1259\end{array}$ & incidence & $\begin{array}{l}\text { APC } x \operatorname{sex} x \\
\text { ethnicity }\end{array}$ & 19 \\
\hline $\begin{array}{l}\text { Nancy You, } \\
2012[5]\end{array}$ & USA & National Cancer Database & $\begin{array}{l}\text { colon, } \\
\text { rectum }\end{array}$ & ICD-O-3 & stage III, IV & $<50$ & 64,068 & incidence & APC $\times$ site & 18 \\
\hline $\begin{array}{l}\text { Austin, } \\
2014[22]\end{array}$ & USA & CDC NPCR & $\begin{array}{l}\text { proximal colon, } \\
\text { distal colon, } \\
\text { rectum }\end{array}$ & ICD-O-3 & $\begin{array}{l}\text { local, regional, } \\
\text { distal }\end{array}$ & $<50$ & $\begin{array}{l}\text { not } \\
\text { reported }\end{array}$ & incidence & $\begin{array}{l}\text { 1. APC } x \\
\text { ethnicity } \\
\text { 2. APC x sex x } \\
\text { ethnicity }\end{array}$ & 18 \\
\hline $\begin{array}{l}\text { Siegel, } 2014 \\
{[23]}\end{array}$ & USA & SEER-13, CDC NPCR & $\begin{array}{l}\text { proximal colon, } \\
\text { distal colon, } \\
\text { rectum }\end{array}$ & ICD-O-3 & $\begin{array}{l}\text { local, regional, } \\
\text { distal }\end{array}$ & $<50$ & $\begin{array}{l}\text { w: } 6250 \\
\text { m: } 7270\end{array}$ & $\begin{array}{l}\text { incidence } \\
\text { mortality }\end{array}$ & APC $\times$ site & 17 \\
\hline $\begin{array}{l}\text { Singh, } 2014 \\
{[24]}\end{array}$ & USA & California Cancer Registry & $\begin{array}{l}\text { proximal colon, } \\
\text { distal colon, } \\
\text { rectum }\end{array}$ & ICD-O-3 & $\begin{array}{l}\text { local, regional, or } \\
\text { distant }\end{array}$ & $\begin{array}{l}20 \text { to } \\
49\end{array}$ & 20,520 & incidence & $\begin{array}{l}\text { BAPC } x \operatorname{sex} x \\
\text { age }\end{array}$ & 19 \\
\hline $\begin{array}{l}\text { Bailey, } 2015 \\
{[6]}\end{array}$ & USA & SEER-9 & $\begin{array}{l}\text { colon, } \\
\text { rectum }\end{array}$ & $\begin{array}{l}\text { not } \\
\text { reported }\end{array}$ & $\begin{array}{l}\text { localized, regional, } \\
\text { distant }\end{array}$ & $\begin{array}{l}20 \text { to } \\
49\end{array}$ & 30,708 & incidence & $\begin{array}{l}\text { 1. } A P C \times \text { age } \\
\text { 2. } A P C x \text { age } x \\
\text { site }\end{array}$ & 18 \\
\hline $\begin{array}{l}\text { Rahman, } \\
2015 \text { [25] }\end{array}$ & USA & $\begin{array}{l}\text { SEER-18, North American } \\
\text { Association of Central Cancer } \\
\text { Registries }\end{array}$ & colorectal & $\begin{array}{l}\text { not } \\
\text { reported }\end{array}$ & stage 0, I, II, II, IV & $<50$ & 60,023 & $\begin{array}{l}\text { incidence } \\
\text { mortality }\end{array}$ & AAPC & 17 \\
\hline $\begin{array}{l}\text { Patel, } 2016 \\
{[26]}\end{array}$ & Canada & $\begin{array}{l}\text { National Cancer Incidence } \\
\text { Reporting System, CCR, Quebec } \\
\text { Cancer Registry }\end{array}$ & $\begin{array}{l}\text { colon, } \\
\text { rectum }\end{array}$ & ICD-O-3 & not reported & $\begin{array}{l}15 \text { to } \\
49\end{array}$ & $\begin{array}{l}\text { 1969: } \\
756 \\
2010: \\
1475\end{array}$ & incidence & $\begin{array}{l}\text { 1. } A P C \times \text { age } \\
\text { 2. } A P C \times \text { sex } x \\
\text { age }\end{array}$ & 20 \\
\hline $\begin{array}{l}\text { Koblinkski, } \\
2017\end{array}$ & US & SEER-18 & colorectal & $\begin{array}{l}\text { not } \\
\text { reported }\end{array}$ & $\begin{array}{l}\text { local, regional, } \\
\text { distal }\end{array}$ & $<50$ & $\begin{array}{l}\text { not } \\
\text { reported }\end{array}$ & incidence & $\begin{array}{l}\text { percent } \\
\text { change } x \\
\text { ethnicity } x \\
\text { stage }\end{array}$ & 16 \\
\hline $\begin{array}{l}\text { Sheneman, } \\
2017 \text { [27] }\end{array}$ & US & Colorado Cancer Registry & colorectal & ICD-O-3 & early, late & $<50$ & 3729 & incidence & $\begin{array}{l}\text { 1. EAPC } \\
\text { 2. EAPC x sex }\end{array}$ & 18 \\
\hline $\begin{array}{l}\text { Siegel, } 2017 \\
\text { [7] }\end{array}$ & US & SEER-9, CDC NPCR & $\begin{array}{l}\text { proximal colon, } \\
\text { distal colon, } \\
\text { rectum }\end{array}$ & ICD-O-3 & $\begin{array}{l}\text { local, regional, } \\
\text { distal }\end{array}$ & $\begin{array}{l}0 \text { to } \\
49\end{array}$ & $\begin{array}{l}\text { w: } 6650 \\
\text { m: } 7550\end{array}$ & $\begin{array}{l}\text { incidence } \\
\text { mortality }\end{array}$ & $\begin{array}{l}\text { 1. AAPC } \times \text { site } \\
\text { 2. IRR } \times \text { site }\end{array}$ & 17 \\
\hline $\begin{array}{l}\text { Siegel, } 2017 \\
{[7]}\end{array}$ & US & SEER-9 & $\begin{array}{l}\text { proximal colon, } \\
\text { distal colon, } \\
\text { rectum }\end{array}$ & ICD-O-3 & not reported & $\begin{array}{l}20 \text { to } \\
49\end{array}$ & $\begin{array}{l}\text { not } \\
\text { reported }\end{array}$ & incidence & $\begin{array}{l}\text { APC } x \text { age } x \\
\text { site }\end{array}$ & 19 \\
\hline $\begin{array}{l}\text { Wang, } 2017 \\
{[28]}\end{array}$ & US & Texas Cancer Registry & colorectal & ICD-O-3 & $\begin{array}{l}\text { localized, regional, } \\
\text { distant }\end{array}$ & $\begin{array}{l}20 \text { to } \\
49\end{array}$ & 13,028 & $\begin{array}{l}\text { incidence } \\
\text { mortality }\end{array}$ & APC $\times$ age & 17 \\
\hline
\end{tabular}


Table 1 Characteristics of included studies according to continent/region (Continued)

\begin{tabular}{|c|c|c|c|c|c|c|c|c|c|c|}
\hline \multirow[t]{2}{*}{ Study } & \multirow[t]{2}{*}{ Country } & \multirow[t]{2}{*}{ Population /Data Source } & \multicolumn{3}{|c|}{ Cancer Information } & \multirow{2}{*}{$\begin{array}{l}\mathrm{yCRC} \\
\text { age } \\
\text { range } \\
\text { (yr) }\end{array}$} & \multirow{2}{*}{$\begin{array}{l}\mathrm{N}(\mathrm{yCRC} \\
\text { cases) }\end{array}$} & \multicolumn{2}{|l|}{ Outcomes } & \multirow{2}{*}{$\begin{array}{l}\text { Quality } \\
\text { Score }\end{array}$} \\
\hline & & & Site & Definition & Stage & & & $\begin{array}{l}\text { Primary/ } \\
\text { Secondary }\end{array}$ & $\begin{array}{l}\text { Incidence/ } \\
\text { Prevalence } \\
\text { Trend }\end{array}$ & \\
\hline $\begin{array}{l}\text { Ansa, } 2018 \\
{[29]}\end{array}$ & US & SEER-18 & $\begin{array}{l}\text { proximal colon, } \\
\text { distal colon, } \\
\text { rectum }\end{array}$ & ICD-O-3 & $\begin{array}{l}\text { localized, regional, } \\
\text { distant, or } \\
\text { unstaged }\end{array}$ & $\begin{array}{l}0 \text { to } \\
49\end{array}$ & 57,938 & incidence & APC $\times$ age & 18 \\
\hline $\begin{array}{l}\text { Crosbie, } \\
2018 \text { [30] }\end{array}$ & US & SEER-9 & colorectal & ICD-O-3 & not reported & $\begin{array}{l}20 \text { to } \\
49\end{array}$ & $\begin{array}{l}\text { w: } 4010 \\
\text { m: } 4578\end{array}$ & incidence & APC $x$ sex & 19 \\
\hline $\begin{array}{l}\text { Ellis, } 2018 \\
{[31]}\end{array}$ & US & California Cancer Registry & colorectal & $\begin{array}{l}\text { not } \\
\text { reported }\end{array}$ & $\begin{array}{l}\text { in situ, localized, } \\
\text { regional, distant }\end{array}$ & $\begin{array}{l}20 \text { to } \\
49\end{array}$ & $\begin{array}{l}\text { w: } 1304 \\
\text { m: } 1276\end{array}$ & incidence & $\begin{array}{l}\text { TAPC } \times \text { sex } x \\
\text { ethnicity }\end{array}$ & 18 \\
\hline $\begin{array}{l}\text { Garcia, } 2018 \\
{[32]}\end{array}$ & US & SEER-18, CDC NPCR & colorectal & ICD-O-3 & $\begin{array}{l}\text { localized, regional, } \\
\text { distant }\end{array}$ & $\begin{array}{l}20 \text { to } \\
49\end{array}$ & $\begin{array}{l}\text { not } \\
\text { reported }\end{array}$ & incidence & $\begin{array}{l}\text { relative change } \\
\text { in } \mathbb{R}\end{array}$ & 18 \\
\hline $\begin{array}{l}\text { Jacobs, } \\
2018[33]\end{array}$ & US & SEER-9 & $\begin{array}{l}\text { colon, } \\
\text { rectum }\end{array}$ & ICD-O-3 & Stage $0-2,3,4$ & $<55$ & $\begin{array}{l}\text { not } \\
\text { reported }\end{array}$ & incidence & $\%$ change of $\mathbb{R}$ & 19 \\
\hline \multicolumn{11}{|c|}{ Oceania ( $n=4$ studies) } \\
\hline $\begin{array}{l}\text { Haggar, } \\
2012[34]\end{array}$ & Australia & $\begin{array}{l}\text { Western Australia Data Linkage } \\
\text { Service }\end{array}$ & colorectal & ICD-O-3 & not reported & $\begin{array}{l}15 \text { to } \\
39\end{array}$ & 500 & $\begin{array}{l}\text { incidence } \\
\text { mortality }\end{array}$ & $\mathrm{APC} \times \mathrm{sex}$ & 18 \\
\hline $\begin{array}{l}\text { Boyce, } 2016 \\
{[35]}\end{array}$ & Australia & $\begin{array}{l}\text { New South Wales Central Cancer } \\
\text { Registry }\end{array}$ & $\begin{array}{l}\text { colon, } \\
\text { rectum }\end{array}$ & $\begin{array}{l}\text { ICD-O-3 } \\
\text { and ICD- } \\
10\end{array}$ & $\begin{array}{l}\text { localised, regional, } \\
\text { distant }\end{array}$ & $\begin{array}{l}<30 \\
\text { to } 49\end{array}$ & $\begin{array}{l}\text { w: } 971 \\
\text { m: } 1030\end{array}$ & $\begin{array}{l}\text { incidence } \\
\text { mortality }\end{array}$ & $\begin{array}{l}\text { average annual } \\
\text { linear trend in } \\
\mathrm{R}\end{array}$ & 19 \\
\hline $\begin{array}{l}\text { Gandhi, } \\
2017[36]\end{array}$ & $\begin{array}{l}\text { New } \\
\text { Zealand }\end{array}$ & New Zealand Cancer Registry & $\begin{array}{l}\text { proximal colon, } \\
\text { distal colon, } \\
\text { rectum }\end{array}$ & $\begin{array}{l}\text { not } \\
\text { reported }\end{array}$ & not reported & $<50$ & $\begin{array}{l}\text { not } \\
\text { reported }\end{array}$ & incidence & $\begin{array}{l}\text { rate of change } \\
\text { of IR }\end{array}$ & 19 \\
\hline $\begin{array}{l}\text { Troeung, } \\
2017[37]\end{array}$ & Australia & Western Australia Cancer Registry & colorectal & $\begin{array}{l}\text { ICD-9 } \\
\text { and ICD- } \\
10\end{array}$ & tumour grade & $\begin{array}{l}15 \text { to } \\
39\end{array}$ & $\begin{array}{l}\text { w: } 256 \\
\text { m: } 261\end{array}$ & $\begin{array}{l}\text { incidence } \\
\text { mortality }\end{array}$ & $\begin{array}{l}\text { 1. APC overall } \\
\text { 2. APC x sex }\end{array}$ & 19 \\
\hline \multicolumn{11}{|c|}{ Europe ( $n=3$ studies) } \\
\hline $\begin{array}{l}\text { Zaridze, } \\
1990[38]\end{array}$ & Russia & not well described & $\begin{array}{l}\text { colon, } \\
\text { rectum }\end{array}$ & $\begin{array}{l}\text { not } \\
\text { reported }\end{array}$ & not reported & $\begin{array}{l}<29 \\
\text { to } 49\end{array}$ & $\begin{array}{l}\text { not } \\
\text { reported }\end{array}$ & incidence & $\begin{array}{l}\text { APC } x \text { type } x \\
\text { sex } x \text { age }\end{array}$ & 9 \\
\hline $\begin{array}{l}\text { Larsen, } \\
2010[39]\end{array}$ & Norway & Cancer Registry of Norway & $\begin{array}{l}\text { colon, } \\
\text { rectum }\end{array}$ & ICD-7 & not reported & $\begin{array}{l}35 \text { to } \\
54\end{array}$ & $\begin{array}{l}\text { w: } 1739 \\
\text { m: } 1707\end{array}$ & incidence & APC $\times$ age & 18 \\
\hline $\begin{array}{l}\text { Ullah, } 2018 \\
{[40]}\end{array}$ & Ireland & $\begin{array}{l}\text { National Cancer Registry of } \\
\text { Ireland }\end{array}$ & colorectal & $\begin{array}{l}\text { not } \\
\text { reported }\end{array}$ & not reported & $\begin{array}{l}20 \text { to } \\
49\end{array}$ & 2750 & incidence & APC $\times$ age & 18 \\
\hline \multicolumn{11}{|c|}{ Asia ( $n=6$ studies) } \\
\hline $\begin{array}{l}\text { Nooyi, } 2011 \\
{[41]}\end{array}$ & India & $\begin{array}{l}\text { Indian Population-Based Cancer } \\
\text { Registries }\end{array}$ & rectum & ICD-O & not reported & $\begin{array}{l}35 \text { to } \\
49\end{array}$ & $\begin{array}{l}\text { not } \\
\text { reported }\end{array}$ & incidence & $\begin{array}{l}\text { EAPC } \times \operatorname{sex} x \\
\text { age }\end{array}$ & 16 \\
\hline $\begin{array}{l}\text { Wu, } 2012 \\
{[42]}\end{array}$ & China & Shanghai Cancer Registry & colorectal & ICD-9 & not reported & $\begin{array}{l}15 \text { to } \\
49\end{array}$ & $\begin{array}{l}\text { w: } 312 \\
\text { m: } 259\end{array}$ & incidence & APC $x$ sex & 19 \\
\hline $\begin{array}{l}\text { Zhou, } 2015 \\
\text { [43] }\end{array}$ & China & Guangzhou Cancer Registry & colon, rectum & ICD-10 & not reported & $<50$ & $\begin{array}{l}\text { not } \\
\text { reported }\end{array}$ & incidence & $\begin{array}{l}\text { 1. } A P C \\
\text { 2. } A P C \times \text { sex }\end{array}$ & 18 \\
\hline $\begin{array}{l}\text { Nakagawa, } \\
2017[44]\end{array}$ & Japan & $\begin{array}{l}\text { Japanese Population-Based Can- } \\
\text { cer Registries }\end{array}$ & $\begin{array}{l}\text { colon, } \\
\text { rectum }\end{array}$ & ICD-10 & not reported & $<50$ & $\begin{array}{l}\text { not } \\
\text { reported }\end{array}$ & incidence & $\begin{array}{l}\text { 1. APC x } \\
\text { overall } \\
\text { 2. APC } x \text { site }\end{array}$ & 19 \\
\hline $\begin{array}{l}\text { Sarakarn, } \\
2017[45]\end{array}$ & Thailand & Khon Kaen Cancer Registry & colorectal & ICD-O & $\begin{array}{l}\text { stage I, II, III, and } \\
\text { IV }\end{array}$ & $<50$ & $\begin{array}{l}\text { w: } 1566 \\
\text { m: } 1798\end{array}$ & incidence & $\begin{array}{l}\text { 1. } A P C \\
\text { 2. } A P C \times \text { sex }\end{array}$ & 17 \\
\hline $\begin{array}{l}\text { Zhang, } \\
2018[46]\end{array}$ & China & Hong Kong Cancer Registry & $\begin{array}{l}\text { colon, } \\
\text { rectum }\end{array}$ & $\begin{array}{l}\text { not } \\
\text { reported }\end{array}$ & not reported & $\begin{array}{l}20 \text { to } \\
49\end{array}$ & 8829 & incidence & $\begin{array}{l}\text { APC } x \operatorname{sex} x \\
\text { type }\end{array}$ & 20 \\
\hline \multicolumn{11}{|c|}{ Africa ( $n=1$ study) } \\
\hline Hamdi & Algeria & $\begin{array}{l}\text { Population-Based Cancer } \\
\text { Registry of Setif }\end{array}$ & colorectal & ICD-O-3 & not reported & $\begin{array}{l}15 \text { to } \\
44\end{array}$ & $\begin{array}{l}\text { not } \\
\text { reported }\end{array}$ & incidence & APC $x$ sex & 19 \\
\hline
\end{tabular}

Abbreviations: $A P C$ annual percent change (in incidence or prevalence); $A A P C$ average annual percent change; $A S R$ age-standardized incidence rate; $B A P C$ biannual annual percent change; EAPC estimated annual percent change; TAPC triannual percent change; $I R$ incidence rate; $w$ women; $m$ men; $y C R C$ young-onset colorectal cancer; CDC Centre for Disease Control; ICD-O International Classification of Diseases for Oncology; ICD International Classification of Diseases;

SEER Surveillance, Epidemiology, and End Results Program Registry;

$C C R$ Canadian Cancer Registry;

CDC NPCR Centre for Disease Control National Program for Cancer Registries 
men (Supplementary Figure 3) from 1982 to 2014 [15, $17,21,30,37,42]$.

With respect to our primary outcome of trends in yCRC incidence, included studies varied across reported trend measures - for example APCi in 22 studies [4, 5, 17, 18, 21-23, 26, 28-30, 34, 37, 38, 40, 42-44, 46, 47, 49,50 ], extensions of the APCi (average APCi [AAPCi], estimated APCi [EAPCi]) in 10 studies [14, 16, 24, 25, $27,31,39,41,45,48]$, and other measures such as \% changes in incidence rates, incidence rate ratios, and odds ratios in seven studies $[15,19,32,33,35,36,51]$. Studies also varied in how they reported these incidence trends - 15 provided overall estimates $[5,6,18,23,25$, $28,29,32,33,35,40,44,48,50,51], 17$ according to sex [4, 14-17, 19, 21, 24, 31, 34, 36, 38, 39, 41, 42, 46, 47], and seven provided both overall and sex-specific estimates [22, 26, 27, 30, 37, 43, 45].

Table 2 summarizes results of meta-analyses of the most commonly reported trend estimate - the APCi overall, by sex, and by continent. Overall, we obtained pooled APCi of +1.33 (95\% CI, 0.97 to $1.68 ; p<0.0001$ ). When we meta-analyzed studies that reported sexspecific APCi, we obtained a pooled APCi of $+1.02(95 \%$ CI, 0.21 to $1.83 ; p=0.02)$ for women and $+0.99(95 \% \mathrm{CI}$, 0.31 to $1.67 ; p=0.006$ ) for men. Further columns in Table 2 show no marked changes in pooled APCi overall with various sensitivity analyses that attempted to account for potential overlap in data from included studies from the USA, particularly those using SEER. In the following, we present our synthesis of findings on trends in yCRC incidence according to continent with Table 3 summarizing reported trends.

\section{North America}

The majority of studies in our systematic review are from North America with 25 studies altogether [4-7, $14-30,32,33,48,51]$ and 23 from the USA [4-7, 14, 15, 17-19, 21-25, 27-30, 32, 33, 48, 51]. Among studies from the USA, 12 reported overall estimates and consistently showed increasing incidence of yCRC, largely driven by rectal cancer in eight studies $[5,17,18,23,33$, $48,50]$. The earliest of these studies by Meyer et al. in 2010 analyzed SEER-9 data and reported an APCi of + 2.6 (95\% CI, 1.9 to 3.3 ) for rectal cancer and - $0.2(95 \%$ CI, -0.6 to 0.3 ) for colon cancer [18]. Using SEER-9 data in 2015, Bailey et al. highlighted the increasing risk of rectal cancer, with APCi's of $+4.03(p<0.001)$ for localized, $+3.05(p<0.001)$ for regional, and $+2.66(p<$ 0.001 ) for distant disease and estimated that incidence rates of rectal cancers for patients under 50 years are expected to increase up to $124.2 \%$ by 2030 [6]. Siegel et al. published one study in 2009 (SEER-13) [4], one in 2014 (SEER-13) [23], and two in 2017 (SEER-9) [7, 48] that consistently showed the contributions of rectal cancer to

Table 2 Pooled annual percent change in incidence $\left(A P C_{i}\right), 95 \%$ confidence intervals, and p-values for yCRC overall, according to sex, and continent

\begin{tabular}{|c|c|c|c|c|c|c|c|c|}
\hline & \multicolumn{2}{|l|}{ Primary Analysis $\ddagger$} & \multicolumn{2}{|c|}{ Sensitivity Analysis $1 * \ddagger$} & \multicolumn{2}{|c|}{ Sensitivity Analysis 2*‡ } & \multicolumn{2}{|c|}{ Sensitivity Analysis $3^{*} \ddagger$} \\
\hline & $\begin{array}{c}\text { pooled APC } \\
(95 \% \mathrm{CI})\end{array}$ & p-value & $\begin{array}{c}\text { pooled APC } \\
(95 \% \mathrm{CI})\end{array}$ & p-value & $\begin{array}{c}\text { pooled APC } \\
(95 \% \mathrm{CI})\end{array}$ & p-value & $\begin{array}{c}\text { pooled APC } \\
(95 \% \mathrm{CI})\end{array}$ & p-value \\
\hline \multicolumn{9}{|c|}{ Pooling according to reporting of $\mathrm{APCi}$} \\
\hline Overall & $1.33(0.97,1.68)$ & $<0.0001$ & $1.32(0.89,1.74)$ & $<0.0001$ & $1.38(0.96,1.80)$ & $<0.0001$ & $1.30(0.83,1.78)$ & $<0.0001$ \\
\hline Women & $1.02(0.21,1.83)$ & 0.02 & $1.18(0.29,2.06)$ & 0.01 & $1.18(0.29,2.06)$ & 0.01 & $1.17(0.26,2.08)$ & 0.01 \\
\hline Men & $0.99(0.31,1.67)$ & 0.006 & $1.02(0.21,1.82)$ & 0.02 & $1.02(0.21,1.82)$ & 0.02 & $0.99(0.17,1.80)$ & 0.02 \\
\hline \multicolumn{9}{|c|}{ Pooling according to continent } \\
\hline North America & $1.59(1.24,1.93)$ & $<0.0001$ & $1.72(0.77,2.68)$ & 0.002 & $1.74(1.32,2.15)$ & $<0.0001$ & $1.69(1.21,2.17)$ & $<0.0001$ \\
\hline Oceania & $1.75(-0.35,3.85)$ & 0.08 & & & & & & \\
\hline Europe & $-0.70(-4.75,3.36)$ & 0.72 & & & & & & \\
\hline Asia & $-0.23(-0.91,0.45)$ & 0.49 & & & & & & \\
\hline
\end{tabular}

*Sensitivity analyses to obtain pooled APCi overall, for women and men, and for North America were based on included USA studies using SEER data to account for potential overlap between studies; pooled APCi's for Oceania, Europe, and Asia were unchanged as they were not subject to sensitivity analyses given fewer studies and different data sources;

-Primary analysis included 16 USA studies reporting $\mathrm{APC}_{\mathrm{i}}$ and thus represent the most inclusive pooling scenario.

-Sensitivity analysis 1 included 11 USA studies

-Sensitivity analysis 2 included 9 USA studies

-Sensitivity analysis 3 included 7 USA studies

‡Cochran’s Q-test non-significant and I-squared statistic (=0), suggesting no evidence of heterogeneity

\footnotetext{
* Sensitivity analyses to obtain pooled APCi overall, for women and men, and for North America were based on included USA studies using SEER data to account for potential overlap between studies; pooled APCi's for Oceania, Europe, and Asia were unchanged as they were not subject to sensitivity analyses given fewer studies and different data sources;

-Primary analysis included 16 USA studies reporting $A P C_{i}$ and thus represent the most inclusive pooling scenario.

-Sensitivity analysis 1 included 11 USA studies

-Sensitivity analysis 2 included 9 USA studies

-Sensitivity analysis 3 included 7 USA studies

‡Cochran's Q-test non-significant and I-squared statistic $(=0)$, suggesting no evidence of heterogeneity
} 
the increasing risk of yCRC. In their most recent study in 2017, they showed that the age-adjusted proportion of incident cases in adults 55 years and younger increased from $14.6 \%$ (95\% CI, 14.0 to $15.2 \%$ ) to $29.2 \%$ (95\% CI, 28.5 to $29.9 \%$ ) for rectal cancer (18). Of note, studies from the USA also allowed for evaluation of sex-specific and ethnicity-specific trends in yCRC incidence. Eight studies reported estimates according to sex with four showing increasing incidence of $\mathrm{yCRC}$ in both women and men [4, 17, 19, 24]. Ethnicity-specific trends were reported in 17 USA studies $[4,5,14,18,19,21,22,24$, $25,27-33,48,51]$. We observed consistently reported increases in yCRC incidence among non-Hispanic White $[4,22,48]$, White $[18,19,51]$, and Black patients [18].

We also identified two studies from Canada $[16,20$, 26]. In 2002, Marrett et al. reported decreasing incidence of yCRC with AAPCi's from 1969 to 1996 of -1.39 (95\% $\mathrm{CI},-1.69$ to -1.08 ) for women between 20 and 44 years and $-0.43(95 \% \mathrm{CI},-0.77$ to -0.08$)$ for men [16]. However, the more recent study in 2016 by Patel et al. reported APCi values ranging from $+0.6(95 \% \mathrm{CI}, 0.1$ to 1.2 ; 40 to 49 years) to +7.9 ( $95 \% \mathrm{CI}, 1.1$ to $15.1 ; 15$ to 29 years) for women and from $+1.0(95 \% \mathrm{CI}, 0.4$ to 1.5 ; 40 to 49 years) to +7.0 (95\% CI, 3.7 to $10.4 ; 15$ to 29 years) for men [26].

Altogether, when we meta-analyzed APCi's reported overall across studies from North America, we obtained a pooled APCi of +1.59 (95\% CI, 1.24 to $1.93 ; p<$ 0.0001 ). Various pooling scenarios that attempted to account for potential overlap in data from included USA studies did not result in marked changes, though somewhat higher pooled APCi's (as shown in Table 2) suggest that meta-analyzing across all included studies yielded the most conservative (e.g. lowest) estimate.

\section{Oceania}

We included four studies from Oceania [34-37]. Three studies from Australia showed an increasing risk of yCRC [34, 35, 37], particularly among women [34, 37]. In 2012, Haggar et al. showed this increasing trend in yCRC among women (APCi, + 1.4; 95\%, 0.1 to 2.7) but not for men (APCi, $-0.4 ; 95 \%,-1.7$ to 1.0 ) [34]. In 2017, Troeung et al. similarly found increasing risk of yCRC among women ( $\mathrm{APCi},+3.4 ; 95 \% \mathrm{CI}, 1.1$ to 5.7 ) but not among men (APCi, +2.6 ; $95 \% \mathrm{CI},-0.9$ to 5.2 ) [37]. In 2017 in New Zealand, Gandhi et al. reported incidence rate ratios that suggested increased risk of rectal cancer for both women (IRR 1.13; 95\% CI, 1.2 to 1.26 ) and men (IRR 1.18; 95\% CI, 1.06 to 1.32 ) less than 50 years [36]. Meta-analyzing reported overall APCi's yielded the highest point estimate across all continents of 1.75 for Oceania, though not statistically significant (95\% CI, -0.35 to $3.85 ; p=0.08$ ).

\section{Europe}

We included three studies from Europe [38-40]. In a Russian study, Zaridze et al. reported APCi's according to sex, cancer type, and age group but no consistent trends in yCRC epidemiology were noted [38]. In their 2010 study, Larsen and Bray did not show significant changes in yCRC incidence among 35 to 54 year-olds, with an APCi between -2 and +1 for both women and men [39]. The most recent study in 2018 from Ireland by Ullah et al. reported inconsistent findings with APCi of $+9.17(p<0.03)$ for 20 to 29 year-olds, $+4.6(p=0.1)$ for 30 to 39 year-olds, and $+0.83(p=0.45)$ for 40 to 49 year-olds [40]. When we meta-analyzed reported overall APCi's, we obtained a pooled APCi of - 0.70 (95\% CI, 4.76 to $3.36 ; p=0.72$ ) for European studies.

\section{Asia}

We identified six studies from Asia [41-46]. The only increasing trend for yCRC was found in Thailand by Sarakarn et al. who reported an AAPCi of +5.7 between 1989 and 2012 for patients under 50 years overall, and significant trends for both women (AAPCi, + 5.7; $p<$ $0.05)$ and men (AAPCi, + 3.2; $p<0.05)$ [45]. In contrast, a decreasing trend for rectal cancer in patients less than 50 years was reported in Japan (APCi, - 1.9; 95\% CI, 2.6 to -1.1 [ [44]. Three studies from China reported conflicting findings $[42,43,46]$. Zhou et al. (2015) reported a decrease in incidence with an APCi of - 3.1 $(p<0.05)$ for yCRC [43]; Wu et al. reported no change in incidence with APCi's of -0.3 (95\% CI, -0.9 to 0.3$)$ in women and $+0.1(95 \% \mathrm{CI},-0.4$ to 0.4$)$ in men aged 15 to 49 years [42]; while Zhang et al. did not show consistent findings [46]. When we meta-analyzed similarly reported overall APCi's, we obtained a pooled estimate of $-0.22(95 \% \mathrm{CI},-0.91$ to $0.45 ; p=0.49)$ for studies from Asia.

\section{Africa \\ One included study from Africa used the Cancer Regis- try of Setif, Algeria from 1986 to 2010 and reported no change in yCRC incidence with APCi's of CRC among patients 15 to 44 years of -2.1 ( $95 \% \mathrm{CI},-6.3$ to 2.3$)$ for women and -0.8 (95\% CI, -4.7 to 3.3) for men [47].}

\section{Secondary outcomes}

Among included studies, seven reported additional information on survival $[25,28,35]$ or mortality $[23,34$, $37,48]$ in yCRC. With respect to survival, Rahman et al. (2015) reported five-year relative survival for yCRC in the USA for Non-Hispanic Whites as 65.5\%, African Americans as $56.4 \%$, Hispanics as $62.0 \%$, Asians as 65.9\%, and Pacific Islanders, American Indians, and Alaska Natives as 59.8\% [25]. In 2017, Wang et al. examined yCRC among Hispanics in the USA and reported a 
Table 3 Reported trends in incidence of yCRC incidence overall and according to sex

\begin{tabular}{|c|c|c|c|c|c|}
\hline Study & $\begin{array}{l}\text { Date } \\
\text { Range }\end{array}$ & Overall & Women & Men & Findingb \\
\hline \multicolumn{6}{|l|}{ North America } \\
\hline Chow 1991 [1991] & 1976-1987 & - & $\begin{array}{l}\text { CC AAPC White: }-2.0(<0.05) \\
\text { CC AAPC Black: }-1.3\end{array}$ & $\begin{array}{l}\text { CC AAPC White: }-0.7 \\
\text { CC AAPC Black: }+1.7\end{array}$ & $\begin{array}{l}\text { not } \\
\text { consistent }\end{array}$ \\
\hline Polednak, 1994 [15] & 1965-1991 & - & CRC \% change ASR: $-19(p=0.153)$ & CRC \% change ASR: $-29(p<0.05)$ & $\downarrow C R C m$ \\
\hline Marrett 2002 [16] & 1969-1996 & - & CRC AAPC: $-1.39(-1.69,-1.08)$ & CRC AAPC: $-0.43(-0.77,-0.08)$ & $\begin{array}{l}\downarrow C R C w \\
\downarrow C R C f\end{array}$ \\
\hline Cress, 2006 [17] & 1992-2001 & CRC APC: $+1.1^{\mathrm{a}}$ & $\begin{array}{l}\text { CRC APC: }+1.4 \\
\text { RC APC: }+3.6(p<0.05)\end{array}$ & $\begin{array}{l}\text { CRC APC: }+0.8 \\
\text { RC APC: }+2.5(p<0.05)\end{array}$ & $\begin{array}{l}\uparrow R C W \\
\uparrow R C m\end{array}$ \\
\hline Siegel 2009 [4] & 1992-2005 & - & CRC APC: $+1.6(p<0.05)$ & CRC APC: $+1.5(p<0.05)$ & $\begin{array}{l}\uparrow C R C w \\
\uparrow C R C m\end{array}$ \\
\hline Meyer 2010 [18] & 1973-2005 & $\begin{array}{l}\text { CC APC: }-0.2(-0.6,0.3) \\
\text { RC APC: + 2.6 }(1.9,3.3)\end{array}$ & RC APC: + $2.5(1.8,3.8)$ & RC APC: + $2.5(1.6,3.4)$ & $\uparrow R C$ \\
\hline Merrill, 2011 [19] & 2000-2007 & - & $\begin{array}{l}\text { CRC \% change RAIR White: } 21.7 \\
\text { CRC \% change RAIR Black: } 11.4\end{array}$ & $\begin{array}{l}\text { \% change CRC RAIR White: } 2.0 \\
\text { CRC \% change RAIR Black: } 0.4\end{array}$ & $\begin{array}{l}\uparrow C R C w \\
\uparrow C R C m\end{array}$ \\
\hline Giddings, 2012 [21] & 1998-2007 & - & $\begin{array}{l}\text { CRC APC Chinese: }-1.8(-3.9,0.3) \\
\text { CRC APC Japanese: }-0.1(-3.6,3.7) \\
\text { CRC APC Filipino: }-0.1(-2.2,2.1) \\
\text { CRC APC Korean: + } 0.5(-2.0,3.1) \\
\text { CRC APC South Asian: - } \\
\text { CRC APC Vietnamese: + } 2.2(-0.8, \\
5.2)\end{array}$ & $\begin{array}{l}\text { CRC APC Chinese: }-1.6(-3.3,0.1) \\
\text { CRC APC Japanese: + } 1.4(-2.5, \\
\text { 5.6) } \\
\text { CRC APC Filipino: + } 0.6(-1.6,2.9) \\
\text { CRC APC Korean: + } 3.4(0.1,6.7) \\
\text { CRC APC South Asian: + } 1.5(-2.9, \\
\text { 6.2) } \\
\text { CRC APC Vietnamese: + } 1.8(-0.8, \\
\text { 4.4) }\end{array}$ & $\begin{array}{l}\text { not } \\
\text { consistent }\end{array}$ \\
\hline Nancy You 2012 [5] & 1998-2007 & $\begin{array}{l}\text { CRC APC: + } 2.1(1.1,3.1) \\
\text { CC APC: + 2.7 }(2.0,3.3) \\
\text { RC APC: + 3.9 }(3.1,4.7)\end{array}$ & - & - & $\begin{array}{l}\uparrow C R C \\
\uparrow C C \\
\uparrow R C\end{array}$ \\
\hline Austin 2014 [22] & 1998-2009 & $\begin{array}{l}\text { CRC APC } \\
\text { N Hispanic White: }+1.69(1.47,1.91) \\
\text { Black: }+0.44(-0.03,0.92) \\
\text { Asian: }+0.61(-0.41,1.35) \\
\text { Hispanic White: }+0.59(-0.15,1.33)\end{array}$ & $\begin{array}{l}\text { CRC APC } \\
\text { N Hispanic White: }+1.79(1.46,2.11) \\
\text { Blacks: }+0.47(-0.39,1.34) \\
\text { Asian: }+0.45(-0.57,1.49) \\
\text { Hispanic White: }+0.76(0.03,1.5)\end{array}$ & $\begin{array}{l}\text { CRC APC } \\
\text { N Hispanic White: + } 1.61(1.35, \\
1.87) \\
\text { Blacks: }+0.40(-0.14,0.93) \\
\text { Asian: }+0.72(-0.53,1.99) \\
\text { Hispanic White: }+0.42(-0.63, \\
\text { 1.48) }\end{array}$ & $\begin{array}{l}\text { not } \\
\text { consistent }\end{array}$ \\
\hline Siegel 2014 [23] & $2001-2010$ & $\begin{array}{l}\text { CRC APC: }+1.1(p<0.05) \text { RC APC: }+1.8 \\
(p<0.05)\end{array}$ & - & - & $\begin{array}{l}\uparrow C R C \\
\uparrow R C\end{array}$ \\
\hline Singh, 2014 [23] & 1988-2009 & - & $\begin{array}{l}\text { CRC BAPC 20-29y: }+3.8(p<0.011) \\
\text { CRC BAPC 30-39y: + } 4.5(p<0.001) \\
\text { CRC BAPC 40-49y: + } 2.6(p<0.001)\end{array}$ & $\begin{array}{l}\text { CRC BAPC 20-29y: }+2.7(p<0.011) \\
\text { CRC BAPC 30-39y: }+3.5(p<0.001) \\
\text { CRC BAPC 40-49y: }+2.7(p<0.001)\end{array}$ & $\begin{array}{l}\uparrow C R C w \\
\uparrow C R C m\end{array}$ \\
\hline Bailey 2015 [49] & 1975-2010 & $\begin{array}{l}\text { CRC APC 20-34y: + } 1.99(1.48,2.51) \\
\text { CRC APC 35-49y: + } 0.41(0.14,0.69) \\
\text { RC APC 20-34y } \\
\text { localized: + 4.03 }(p<0.001) \\
\text { regional: + } 3.05(p<0.001) \\
\text { distant: + } 2.66(p<0.001) \\
\text { RC APC 35-49y } \\
\text { localized: }+1.62(p<0.001) \\
\text { regional: }+1.37(p<0.001) \\
\text { distant: + } 1.46(p<0.001)\end{array}$ & - & - & $\begin{array}{l}\uparrow C R C \\
\uparrow R C\end{array}$ \\
\hline Rahman 2015 [25] & 1992-2009 & CRC AAPC: + $1.68(p<0.05)$ & - & - & $\uparrow C R C$ \\
\hline Patel 2016 [26] & $\begin{array}{l}1997 \text { to } \\
2010\end{array}$ & $\begin{array}{l}\text { CRC APC 15-29y: + } 6.7(4.3,9.3) \\
\text { CRC APC 30-39y: + } 2.4(1.5,3.3) \\
\text { CRC APC 40-49y: + } 0.8(0.3,1.4)\end{array}$ & $\begin{array}{l}\text { CRC APC 15-29y: + } 7.9(1.1,15.1) \\
\text { CRC APC 30-39y: + } 2.3(0.8,3.7) \\
\text { CRC APC 40-49y: + } 0.6(0.1,1.2)\end{array}$ & $\begin{array}{l}\text { CRC APC 15-29y: + } 7.0(3.7,10.4) \\
\text { CRC APC 30-39y: + } 2.5(1.5,3.4) \\
\text { CRC APC 40-49y: + } 1.0(0.4,1.5)\end{array}$ & $\uparrow C R C$ \\
\hline Koblinski 2017 [51] & $2000-2010$ & $\begin{array}{l}\text { CRC \% change Hispanic } \\
\text { localized: } \uparrow 77 \% \text {; regional: } \uparrow 56 \% \\
\text { distant: } \uparrow 57 \% \\
\text { CRC \% change White } \\
\text { localized: } \uparrow 21 \% \text {; regional: } \uparrow 18 \% \\
\text { distant: } \uparrow 41 \%\end{array}$ & - & - & $\uparrow C R C$ \\
\hline $\begin{array}{l}\text { Sheneman } 2017 \\
\text { [27] }\end{array}$ & 2003-2013 & CRC EAPC: +1.7 & CRC EAPC: +0.6 & CRC EAPC: $+2.7(p<0.05)$ & $\uparrow \mathrm{CRC} \mathrm{m}$ \\
\hline Siegel 2017 [7] & 2004-2013 & $\begin{array}{l}\text { CRC AAPC: + } 1.6(p<0.05) \\
\text { CRC IRR: + } 1.22(1.17,1.28) \\
\text { RC AAPC: + } 2.0(p<0.05)\end{array}$ & - & - & $\begin{array}{l}\uparrow C R C \\
\uparrow \mathrm{RC}\end{array}$ \\
\hline
\end{tabular}


Table 3 Reported trends in incidence of yCRC incidence overall and according to sex (Continued)

\begin{tabular}{|c|c|c|c|c|c|}
\hline Study & $\begin{array}{l}\text { Date } \\
\text { Range }\end{array}$ & Overall & Women & Men & Findingb \\
\hline Siegel 2017 [7] & 1974-2013 & $\begin{array}{l}\text { CC APC 20-29y: + } 2.4(1.6,3.3) \\
\text { CC APC 30-39y: + } 1.0(0.5,1.5) \\
\text { CC APC 40-49y: + } 1.3(0.7,1.8) \\
\text { RC APC 20-29y: + 3.2 }(2.4,3.9) \\
\text { RC APC 30-39y: + 3.2 }(2.7,3.7) \\
\text { RC APC 40-49y: + } 2.3(1.8,2.7)\end{array}$ & - & - & $\begin{array}{l}\uparrow C C \\
\uparrow R C\end{array}$ \\
\hline Wang 2017 [28] & $1995-2010$ & $\begin{array}{l}\text { CRC APC 20-39y: + } 1.82(p<0.01) \\
\text { CRC APC 40-49y: + } 0.33(p=0.08)\end{array}$ & - & - & $\begin{array}{l}\text { no } \\
\text { consistent }\end{array}$ \\
\hline Ansa, 2018 [29] & $2000-2014$ & $\begin{array}{l}\text { CRC APC < 40: }+2.7(p<0.001) \\
\text { CRC APC 40-49y: }+1.7(p<0.001)\end{array}$ & - & - & $\uparrow C R C$ \\
\hline Crosbie, 2018 [30] & 1992-2014 & CRC APC: $+1.8(p<0.05)$ & CRC APC: $+1.8(p<0.05)$ & CRC APC: $+1.7(p<0.05)$ & $\uparrow C R C$ \\
\hline Ellis, 2018 [31] & 2010-2014 & - & $\begin{array}{l}\text { CRC TAPC Chinese: + } 0.1(-2.1,2.4) \\
\text { CRC TAPC Japanese: + } 0.5(-3.1, \\
\text { 4.1) } \\
\text { CRC TAPC Filipino: }-0.6(-3.5,2.4) \\
\text { CRC TAPC Korean: + } 0.8(-3.8,5.5) \\
\text { CRC TAPC South Asian: + } 4.3(-2.0, \\
\text { 10.9) } \\
\text { CRC TAPC Vietnamese: }-0.5(-3.1 . \\
\text { 2.2) } \\
\text { CRC TAPC SEast Asian: - } \\
\text { CRC TAPC White: + } 1.9(0.8,2.9) \\
\text { CRC TAPC Black: + } 0.3(-0.7,1.4) \\
\text { CRC TAPC Hispanic: + } 2.1(1.2,3.1)\end{array}$ & $\begin{array}{l}\text { CRC TAPC Chinese: + } 0.4(-2.0, \\
\text { 2.9) } \\
\text { CRC TAPC Japanese: + } 1.5(-2.0, \\
\text { 5.0) } \\
\text { CRC TAPC Filipino: + } 1.1(-1.1,3.3) \\
\text { CRC TAPC Korean: + } 0.7(-1.8,3.3) \\
\text { CRC TAPC South Asian: }-0.9(- \\
\text { 5.7, 4.2) } \\
\text { CRC TAPC Vietnamese: + } 1.1(-3.9, \\
\text { 6.2) } \\
\text { CRC TAPC SEast Asian: }-1.0(-3.8, \\
\text { 1.9) } \\
\text { CRC TAPC White: }+0.9(0.4,1.4) \\
\text { CRC TAPC Black: }-0.9(-2.2,0.4) \\
\text { CRC TAPC Hispanic: }+1.6(0.3,2.9)\end{array}$ & $\begin{array}{l}\text { not } \\
\text { consistent }\end{array}$ \\
\hline Garcia, 2018 [32] & $2001-2014$ & CRC relative increase IR: $24 \%$ & - & - & $\uparrow \mathrm{CRC}$ \\
\hline Jacobs, 2018 [33] & 1973-2014 & $\begin{array}{l}\text { CC \% change IR: } 41.5(37.4,45.8) \\
\text { RC \% change IR: } 9.8(6.2,13.6)\end{array}$ & & & $\begin{array}{l}\uparrow C R C \\
\uparrow R C\end{array}$ \\
\hline \multicolumn{6}{|l|}{ Oceania } \\
\hline Haggar 2012 [34] & $1982-2007$ & - & CRC APC: + $1.4(0.1,2.7)$ & CRC APC: $-0.4(-1.7,1.0)$ & $\uparrow C R C w$ \\
\hline Boyce 2016 [35] & $2001-2008$ & CRC OR: $1.03(0.99,1.07)$ & - & - & no change \\
\hline Gandhi 2017 [36] & $1975-2012$ & - & RC IRR: $1.13(1.2,1.26)$ & RC IRR: $1.18(1.06,1.32)$ & $\begin{array}{l}\uparrow R C w \\
\uparrow R C m\end{array}$ \\
\hline Troeung 2017 [37] & $1982-2007$ & CRC APC: $+3.0(0.7,5.5)$ & CRC APC: + $3.4(1.1,5.7)$ & CRC APC: $+2.6(-0.9,5.2)$ & $\uparrow C R C w$ \\
\hline \multicolumn{6}{|l|}{ Europe } \\
\hline Zaridze, 1990 [38] & $1971-1987$ & - & $\begin{array}{l}\text { CC APC <29y: }-0.1(-14.2,14.3) \\
\text { CC APC 30-39y: }-1.3(-7.4,5.1) \\
\text { CC APC 40-49y: + 8.2 }(4.6,11.9) \\
\text { RC APC <29y: - } 13.7(-26.4,0.2) \\
\text { RC APC 30-39y: - 9.1 }(-18.3,1.2) \\
\text { RC APC 40-49y: + 4.3 }(0.5,8.3)\end{array}$ & $\begin{array}{l}\text { CC APC <29y: - } 9.1(-17.2,-0.3) \\
\text { CC APC 30-39y: }-2.9(-9.7,4.5) \\
\text { CC APC 40-49y: + 3.2 }(-0.1,6.6) \\
\text { RC APC <29y: }-16.5(-29.3,-1.5) \\
\text { RC APC 30-39y: - } 11.1(-16.4,- \\
\text { 5.4) } \\
\text { RC APC 40-49y: + } 3.7(-1.4,9.1)\end{array}$ & $\begin{array}{l}\text { no } \\
\text { consistent }\end{array}$ \\
\hline Larsen 2010 [39] & 1992-2006 & - & $\begin{array}{l}\text { proximal CC EAPC: } \geq-2 \\
\text { distal CC EAPC: }-1 \\
\text { RC EAPC: }<+1\end{array}$ & $\begin{array}{l}\text { proximal CC EAPC: }<1 \\
\text { distal CC EAPC: } \geq-2 \\
\text { RC EAPC: }<+1\end{array}$ & $\begin{array}{l}\text { no change } \\
\text { w } \\
\text { no change } \\
\text { m }\end{array}$ \\
\hline Ullah, 2018 [40] & 1994-2012 & $\begin{array}{l}\text { CRC APC 20-29y: + } 9.17(p<0.03) \\
\text { CRC APC 30-39y: + } 4.6(p=0.1) \\
\text { CRC APC 40-49y: + } 0.83(p=0.45)\end{array}$ & - & - & $\begin{array}{l}\text { not } \\
\text { consistent }\end{array}$ \\
\hline \multicolumn{6}{|l|}{ Asia } \\
\hline Nooyi, 2011 [41] & 1983-2002 & - & $\begin{array}{l}\text { RC EAPC 35-39 y: - } \\
\text { RC EAPC 40-44y: + } 1.7(p=0.35) \\
\text { RC EAPC 45-49y: + } 0.4(p=0.83)\end{array}$ & $\begin{array}{l}\text { RC EAPC 35-39y: + } 3.1 \quad(p=0.12) \\
\text { RC EAPC 40-44y: + } 1.8(p=0.29) \\
\text { RC EAPC 45-49y: + } 1.4(p=0.41)\end{array}$ & $\begin{array}{l}\text { no change } \\
\text { w } \\
\text { no change } \\
\text { m }\end{array}$ \\
\hline Wu 2012 [42] & $1973-2005$ & - & CRC APC: $-0.3(-0.9,0.3)$ & CRC APC: $0.1(-0.4,0.4)$ & $\begin{array}{l}\text { no change } \\
\text { w } \\
\text { no change } \\
\text { m }\end{array}$ \\
\hline Zhou 2015 [43] & $2005-2011$ & CRC APC: $-3.07(p<0.01)$ & CRC APC: $-2.56(p=0.21)$ & CRC APC: $-3.45(p=0.06)$ & $\downarrow C R C$ \\
\hline Nakagawa 2017 [44] & 1987-2004 & $\begin{array}{l}\text { CRC APC: }-0.8(-1.7,0.1) \\
\text { RC APC: }-1.9(-2.6,-1.1)\end{array}$ & - & - & $\downarrow R C$ \\
\hline Sarakarn 2017 [45] & 1989-2012 & CRC AAPC: +5.7 & CRC AAPC: $+5.7(p<0.05)$ & CRC AAPC: $+3.2(p<0.05)$ & $\uparrow C R C w$ \\
\hline
\end{tabular}


Table 3 Reported trends in incidence of yCRC incidence overall and according to sex (Continued)

\begin{tabular}{lllll}
\hline Study & $\begin{array}{l}\text { Date } \\
\text { Range }\end{array}$ & Overall & Women & Men \\
\hline \\
Zhang, 2018 [46] & $1983-2012$ & & \\
\\
\end{tabular}

a- obtained from authors after contacting them; ${ }^{b}$-key finding(s) indicate consistent trends identified from each study

Abbreviations: $C R C$ colorectal cancer; $R C$ rectal cancer; $C C$ colon cancer; $A P C$ annual percent change; $A A P C$ average annual percent change; $A S R$ age-standardized incidence rates; EAPC estimated annual percent change; RAIR risk-adjusted incidence rate; BAPC biannual percent change; TAPC triannual percent change; IRR incidence rate ratio; $O R$ odds ra

five-year survival proportion of $62.4 \%$ among 20 to 39 year-olds and $63.9 \%$ among 40 to 49 year-olds [28]. In Australia, Boyce et al. showed that the five-year survival was higher in those with yCRC ( $<50$ years) as compared to those with average-onset colorectal cancer (aCRC) ( $\geq 50$ years) (67.1\%; $95 \%$ CI, 64.5 to $69.6 \%$ versus $55.8 \%$; 95\% CI, 55.0 to $56.4 \%, p<0.001$ ) and, compared to patients with aCRC, those with yCRC had a 33\% lower risk of disease-related death (adjusted hazard ratio [aHR], 0.67; 95\% CI, 0.61 to 0.74 ) [35]. With respect to trends in yCRC mortality, Haggar et al. reported APCs in ageadjusted mortality rates (per 100,000) from 1982 to 2005 in Western Australia of -2.3 (95\% CI, -3.7 to - 0.8 ) among women and -2.1 (95\% CI, -4.0 to -0.1$)$ among men [34]. However, in the USA, Siegel et al. reported a $13 \%$ increase in mortality rates for yCRC patients from 2000 to 2014 [48].

\section{Discussion}

We identified 40 studies spanning 12 countries across five continents evaluating temporal trends in the incidence and prevalence of $\mathrm{yCRC}$. Altogether, we found an increasing incidence of $\mathrm{yCRC}$ with a worldwide pooled $\mathrm{APCi}$ of +1.33 (95\% CI, 0.97 to $1.68 ; p<0.0001)$, that is largely driven by increasing incidence in the USA, Australia, and Canada with reported overall APCi's up to +7.9 (95\% CI, 1.1 to 15.1$)$ [26] and nearly $30 \%$ increased incidence over 20 years [4, 6]. With comparatively fewer included studies and inconsistent findings, similar conclusions may not necessarily be drawn for studies from Europe, Asia, and Africa. Another finding from our systematic review is that trends of the increasing risk of yCRC appear to be driven by increased rectal cancers shown in nine out of $14[5,6,17,18,23,24,33$, $36,50]$ studies that specifically evaluated it and with APCi's up to $+4.03(p<0.001)$ [6].

To our knowledge, this is the first systematic review assessing the changing epidemiology of yCRC. While narrative reviews of $\mathrm{yCRC}$ have been published $[1,52$,
53], the only prior systematic review specific to yCRC was by O'Connell et al. in 2004, which included 55 studies based on clinical samples of patients [54]. Altogether, studies in this prior systematic review contributed 6425 patients allowing authors to describe clinical characteristics of yCRC including common presenting symptoms (abdominal pain and rectal bleeding), observed delays in diagnosis exceeding six months, and treatment patterns [54]. A specific finding from O'Connell et al.'s prior systematic review that the rectum and sigmoid colon were the most frequent sites (54\% of tumours) is consistent with our findings on the contribution of rectal cancer to the increased incidence of $\mathrm{yCRC}$ at the population level. Interestingly, the authors found no difference in the sex distribution of yCRC with $48.6 \%$ in women and $51.4 \%$ in men [54] and our pooled sex-specific APCi's for women (+ $1.02 ; 95 \% \mathrm{CI}, 0.20$ to 1.83$)$ and men (+ $0.99 ; 95 \% \mathrm{CI}$, 0.31 to 1.67$)$ were similar. These findings have implications for efforts in raising awareness for both women and men on the increasing risk of $\mathrm{yCRC}$, considering biological differences between sexes as well as gender differences, for example, healthcare seeking.

The increasing incidence of yCRC across a number of jurisdictions seen in our systematic review may indeed signal a recent paradigm shift in CRC. Of note, the majority of included studies $(n=31)$ have been published since 2010 with seven published in the past year (2018) alone. Synthesizing these published, peer-reviewed evidence including quality assessment and where feasible, pooling of commonly reported estimates brings areas for attention based on key findings. One of our key findings is the contribution of findings from the USA, Australia, and Canada to the worldwide increased risk of yCRC. Quite timely, our systematic review also builds on Liu et al.'s recently published work taking data from the IARC and using joinpoint regression to calculate APCi's to show the increasing incidence of $\mathrm{yCRC}$ in 11 out of 12 countries [9]. Indeed, it is important to consider these as complementary works as some countries/continents 
represented in included studies in our systematic review were not captured in the aforementioned study and vice versa.

Along with key findings, it is also important to discuss knowledge gaps that we identified from our systematic review. Notably, only one included study evaluated trends in the prevalence of yCRC [20]. It is important to understand the burden of yCRC in terms of trends in prevalence as it is only through population-level examinations of the number of people who have been previously diagnosed with yCRC that we can count and characterize survivors and ultimately inform the longterm impacts of yCRC. Understanding trends in survival and mortality in yCRC is another area identified in our systematic review requiring further investigation to inform contemporary knowledge of this disease. While we noted comparable five-year survival rates among two USA studies [25, 28], a comparison of mortality data suggests conflicting evidence. Specifically, in terms of mortality trends in yCRC, an Australian study indicated that it has decreased for both sexes from 1982 to 2005 in Western Australia [34] while Siegel et al. reported that it has increased from 2000 to 2014 in the USA [5]. Subsequent to the latter article, the same authors published a letter reporting an increasing mortality trend for yCRC in patients 20 to 54 years from 1970 to 2014 $\left(\mathrm{APC}_{\text {mortality }}+1.0 ; 95 \% \mathrm{CI}, 0.7\right.$ to 1.4$)$ [50].

Aside from identifying gaps, our systematic review also has implications for informing future research needs for better understanding of yCRC. Indeed, key findings of an increasing risk of yCRC highlights the need for future research examining reasons for this. As well, findings from our systematic review suggesting that the increased risk in yCRC may be driven by increased risk of rectal cancer among younger adults underscores the need for research on etiologic reasons for the differences in the risk between rectal and colon cancers. Among included studies in the systematic review, only one evaluated population-level determinants of yCRC [5]. Specifically, in addition to examining trends in the incidence of yCRC in the USA, You et al. also reported independent determinants or risk factors for advance stage yCRC (Stage III/IV) which included: 1) younger age (aHR for 18 to 39 year-olds: $1.4,95 \%$ CI, 1.2 to 1.6 ; aHR for 30 to 39 year-olds: $1.21,95 \% \mathrm{CI}, 1.1$ to 1.4 , compared to 40 to 49 year-olds); 2) African-American ethnicity (aHR, 1.2, 95\% CI, 1.1 to 1.3 , compared to White); and 3) insurance status (compared to those with insurance, aHR for those without insurance was $1.2,95 \% \mathrm{CI}, 1.1$ to 1.3 ; and for those on Medicaid, 1.6, 95\% CI, 1.5 to 1.8) [5]. There was no specific evaluation of risk factors with respect to colon or rectal cancer among younger adults. Although they did not evaluate direct associations with yCRC, another included study, by Patel et al. from Canada, evaluated trends in lifestyle factors among Canadians less than 50 years to elucidate if there may be parallel increases with yCRC incidence trends. With a parallel increase in the prevalence of being overweight or obese in adults younger than 50 years, authors described obesity as a potential lifestyle factor influencing the increasing risk of yCRC in Canada [26], which may be consistent in similar countries. Aside from lifestyle factors, there may also be psychosocial factors. For example, the increasing risk of yCRC may be associated with a delay in seeking medical care from young adults [55]. Noteworthy, the observed risk of yCRC may be an under-representation of the true risk due to clinicians dismissing symptoms that may be consistent but not be specific to CRC [5].

Along with providing further confirmatory evidence on the increasing risk of yCRC, findings of our systematic review also lend to the question of the appropriate age for screening for CRC. In 2018, the American Cancer Society lowered the recommended age for averagerisk adults to initiate screening from 50 to 45 years [8]. This has been subject to debate with arguments for including evidence for increasing risk of yCRC and expected benefits while arguments against including lower absolute risk of yCRC compared to CRC and potential issues with adherence $[56,57]$. Recently in January 2018, Abualkhair et al. analyzed the incidence of CRC in 1year age increments using SEER-18 data and showed a steep increase in the incidence of invasive CRC from 49 to 50 years $(46.1 \%$ increase per 100,000$)$ with an IRR of 1.46 (95\% CI, 1.42 to 1.51) [58]. Their findings provide support for earlier screening for CRC by showing a substantial burden of undetected cancers among younger adults who would not normally undergo screening at 50 years [58]. Of note, in addition to discussions on the recommended age for screening, it is also important to consider efforts to increase awareness of the increasing risk of yCRC among patients and healthcare providers. In our recent patient-oriented qualitative study on the experiences of individuals with diagnosis and treatment with yCRC, a key finding was a theme on misdiagnosis and/or delays in diagnoses, with some participants sharing that symptoms and concerns were dismissed [59]. This finding is supported by those from the Colorectal Cancer Alliance's annual survey, which in 2018 reported that $67 \%$ of yCRC patients saw at least two physicians before being diagnosed correctly [59, 60].

Strengths and limitations of our systematic review deserve discussion. All database searches were conducted by an experienced information scientist. Combining two separate but complementary searches was a unique feature of our study that maximized our capture of eligible studies. However, the inclusion of relevant studies may have been limited by publication bias as in any other systematic review. We did not consider abstracts given the 
importance of being able to assess the quality of the included studies. In addition, although we considered articles from many countries, inclusion of only those published in English is a limitation. Also, a potential limitation is that we did not consider reports or data from national cancer registries unless they have been published as peer-reviewed studies and reported trend estimates of yCRC incidence and/or prevalence, in line with our inclusion criteria. The majority of included studies from the USA using potentially overlapping SEER data may also be considered a limitation. However, drawing more nuanced information on yCRC such as sex- and ethnicity-specific trends is only possible with consideration of all included studies; we did not attempt to exclude studies based on potential overlapping data but rather, conducted various sensitivity analyses, which showed no appreciable differences in pooled APCi.

\section{Conclusion}

Overall, by synthesizing findings from peer-reviewed, epidemiologic studies, our systematic review provides empirical evidence that confirms the increased incidence of yCRC, particularly in North America and Australia. Continued efforts for awareness and education to address this increasing risk are warranted along with research to explain this risk so as to identify areas for prevention and intervention.

\section{Supplementary information}

Supplementary information accompanies this paper at https://doi.org/10. 1186/s12885-020-06766-9.

Additional file 1: Figure S1 Forest plot for studies reporting overall incidence rates for yCRC. Figure S2 Forest plot for studies reporting incidence rates for yCRC among. Figure S3 Forest plot for studies reporting incidence rates for $\mathrm{YCRC}$ among men

Additional file 2: Table S1. Database Search Strategy

Additional file 3: Table S2. Quality appraisal checklist

Additional file 4: Table S3. Reported incidence rates (per 100,000) for yCRC overall and according to sex among included studies

\section{Abbreviations}

APC: Annual percent change; CRC: Colorectal cancer; yCRC: Young-onset CRC; IARC: International Agency for Research on Cancer; APCi: Annual percent change in incidence; PRISMA: The Preferred Reporting Items for Systematic Reviews and Meta-Analysis; Cl: Confidence intervals; USA: United States of America; SEER: Surveillance, Epidemiology, and End Results Program; AAPCi: Average annual percent change in incidence; EAPCi: Estimated annual percent change in incidence; aCRC: Average-onset colorectal cancer; aHR: Adjusted hazard ratio

\section{Acknowledgements}

We would like to thank Mary-Doug Wright, BSc, MLS, for working with our research team to develop the systematic review search strategies and for conducting databases searches. We would like to thank Enav Zusman, MSc for her contributions to the meta-analysis of included studies

\section{Authors' contributions}

KS: Conceptualization, systematic review conduct (title, abstract, and manuscript screening, data extraction, quality assessment), meta-analysis, interpretation, writing - original draft, and writing - review and editing; JL: Interpretation, writing - review and editing; ES: Statistical and meta-analysis, writing - original draft, and writing - review and editing; SG: Interpretation, writing - review and editing; CB: Interpretation, writing - review and editing; HD: Review and editing; MDV: Obtained funding, conceptualization, systematic review conduct (title, abstract, and manuscript screening, data extraction, quality assessment), interpretation, writing - original draft, and writing - review and editing. All authors have read and approved the manuscript.

\section{Funding}

This research was funded by a Project Grant from the Canadian Institutes of Health Research, "Examining the epidemiology, treatment, and outcomes in young-onset colorectal cancer" (Funding reference number: PJT-159467). The funder had no role in study design, data collection and analysis, decision to publish, or preparation of the manuscript.

Mr. Saad El Din holds a Canada Graduate Scholarship - Master's Program from the Canadian Institutes of Health Research. The funder had no role in

study design, data collection and analysis, decision to publish, or preparation of the manuscript.

Dr. De Vera holds a Tier 2 Canada Research Chair and is a recipient of a Scholar Award from the Michael Smith Foundation for Health Research. The funder had no role in study design, data collection and analysis, decision to publish, or preparation of the manuscript.

\section{Availability of data and materials}

All data generated or analysed during this study are included in this published article and its supplementary information files.

\section{Ethics approval and consent to participate}

Not applicable.

\section{Consent for publication}

Not applicable.

\section{Competing interests}

The authors have nothing to declare.

\section{Author details}

${ }^{1}$ Faculty of Pharmaceutical Sciences, University of British Columbia, 2405 Wesbrook Mall, Vancouver, BC Canada V6T 1Z3, Canada. ${ }^{2}$ Collaboration for Outcomes Research and Evaluation, 2405 Wesbrook Mall, Vancouver, BC Canada V6T 1Z3, Canada. ${ }^{3}$ Division of Medical Oncology, Department of Medicine, Faculty of Medicine, University of British Columbia, 2775 Laurel Street, 11 th Floor, Vancouver, BC V5Z 1M9, Canada. ${ }^{4}$ BC Cancer, 600 W 10th Ave, Vancouver, BC V5Z 4E6, Canada. ${ }^{5}$ Arthritis Research Canada, 5591 No 3 Rd, Richmond, BC V6X 2C7, Canada. ${ }^{6}$ Department of Surgery, Faculty of Medicine, University of British Columbia, 2775 Laurel Street, 11th Floor, Vancouver, BC V5Z 1M9, Canada. ${ }^{7}$ St. Paul's Hospital, 1081 Burrard St, Vancouver, BC V6Z 1Y6, Canada.

Received: 19 November 2019 Accepted: 20 March 2020

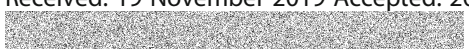

\section{References}

1. Aran V, Victorino AP, Thuler LC, Ferreira CG. Colorectal Cancer: epidemiology, disease mechanisms and interventions to reduce onset and mortality. Clin Colorectal Cancer. 2016;15(3):195-203.

2. Ferlay J, Parkin DM, Steliarova-Foucher E. Estimates of cancer incidence and mortality in Europe in 2008. Eur J Cancer. 2010;46(4):765-81.

3. Abdelsattar ZM, Wong SL, Regenbogen SE, Jomaa DM, Hardiman KM, Hendren S. Colorectal cancer outcomes and treatment patterns in patients too young for average-risk screening. Cancer. 2016;122(6):929-34.

4. Siegel RL, Jemal A, Ward EM. Increase in incidence of colorectal cancer among young men and women in the United States. Cancer Epidemiol Biomark Prev. 2009;18(6):1695-8.

5. Nancy You Y, Xing Y, Feig BW, Chang GJ, Cormier JN. Young-onset colorectal cancer: is it time to pay attention? Arch Intern Med. 2012;172(3): 287-9.

6. Bailey CE, Hu CY, You YN, Bednarski BK, Rodriguez-Bigas MA, Skibber JM Cantor SB, Chang GJ. Increasing disparities in the age-related incidences of 
colon and rectal cancers in the United States, 1975-2010. JAMA Surg. 2015 150(1):17-22.

7. Siegel RL, Fedewa SA, Anderson WF, Miller KD, Ma J, Rosenberg PS, Jemal A. Colorectal Cancer Incidence Patterns in the United States, 1974-2013. J Natl Cancer Inst. 2017;109(8).

8. Wolf AMD, Fontham ETH, Church TR, Flowers CR, Guerra CE, LaMonte SJ, et al. Colorectal cancer screening for average-risk adults: 2018 guideline update from the American Cancer Society. CA Cancer J Clin. 2018;68(4):250-81.

9. Lui RN, Tsoi KK, Ho JM, Lo CM, Chan FC, Kyaw MH, Sung JJ. Global increasing incidence of young-onset colorectal Cancer across 5 continents: a Joinpoint regression analysis of 1,922,167 cases. Cancer Epidemiol Biomark Prev. 2019;21:21.

10. Munn Z, Moola S, Riitano D, Lisy K. The development of a critical appraisal tool for use in systematic reviews addressing questions of prevalence. Int $J$ Health Policy Manag. 2014;3(3):123-8.

11. Downes MJ, Brennan ML, Williams HC, Dean RS. Development of a critical appraisal tool to assess the quality of cross-sectional studies (AXIS). BMJ Open. 2016:6(12):e011458.

12. Sheu CF, Suzuki S. Meta-analysis using linear mixed models. Behav Res Methods Instrum Comput. 2001;33(2):102-7.

13. Huedo-Medina TB, Sánchez-Meca J, Marín-Martínez F, Botella J. Assessing heterogeneity in meta-analysis: Q statistic or 12 index? Psychol Methods. 2006;11(2):193-206.

14. Chow WH, Devesa SS, Blot WJ. Colon cancer incidence: recent trends in the United States. Cancer Causes Control. 1991;2(6):419-25.

15. Polednak AP. Trends in cancer incidence in Connecticut, 1935-1991. Cancer. 1994;74(10):2863-72.

16. Marrett LD, Frood J, Nishri D, Ugnat AM. Cancer in young adults in Canada working G: Cancer incidence in young adults in Canada: preliminary results of a cancer surveillance project. Chronic Dis Can. 2002;23(2):58-64.

17. Cress RD, Morris C, Ellison GL, Goodman MT. Secular changes in colorectal cancer incidence by subsite, stage at diagnosis, and race/ethnicity, 19922001. Cancer. 2006;107(5 Suppl):1142-52.

18. Meyer JE, Narang T, Schnoll-Sussman FH, Pochapin MB, Christos PJ, Sherr DL. Increasing incidence of rectal cancer in patients aged younger than 40 years: an analysis of the surveillance, epidemiology, and end results database. Cancer. 2010;116(18):4354-9.

19. Merrill RM, Anderson AE. Risk-adjusted colon and rectal cancer incidence rates in the United States. Dis Colon Rectum. 2011;54(10):1301-6.

20. Ellison LF, Wilkins K. Canadian trends in cancer prevalence. Health Rep Stat Canada. 2012;23(1) Catalogue no. 82-003-XPE.

21. Giddings BH, Kwong SL, Parikh-Patel A, Bates JH, Snipes KP. Going against the tide: increasing incidence of colorectal cancer among Koreans, Filipinos, and south Asians in California, 1988-2007. Cancer Causes Control. 2012;23(5): 691-702.

22. Austin H, Henley SJ, King J, Richardson LC, Eheman C. Changes in colorectal cancer incidence rates in young and older adults in the United States: what does it tell us about screening. Cancer Causes Control. 2014;25(2):191-201.

23. Siegel R, Desantis C, Jemal A. Colorectal cancer statistics, 2014. CA Cancer J Clin. 2014;64(2):104-17.

24. Singh KE, Taylor TH, Pan CG, Stamos MJ, Zell JA. Colorectal Cancer incidence among young adults in California. J Adolesc Young Adult Oncol. 2014;3(4):176-84.

25. Rahman R, Schmaltz C, Jackson CS, Simoes EJ, Jackson-Thompson J, Ibdah JA. Increased risk for colorectal cancer under age 50 in racial and ethnic minorities living in the United States. Cancer Med. 2015:4(12):1863-70.

26. Patel $P, D e P$. Trends in colorectal cancer incidence and related lifestyle risk factors in 15-49-year-olds in Canada, 1969-2010. J Cancer Epidemiol. 2016; 42:90-100.

27. Sheneman DW, Finch JL, Messersmith WA, Leong S, Goodman KA, Davis SL, Purcell WT, McCarter M, Gajdos C, Vogel J, et al. The impact of young adult colorectal cancer: incidence and trends in Colorado. Colorectal Cancer. 2017;6(2):49-56.

28. Wang DY, Thrift AP, Zarrin-Khameh N, Wichmann A, Armstrong GN, Thompson PA, Bondy ML, Musher BL. Rising incidence of colorectal Cancer among young Hispanics in Texas. J Clin Gastroenterol. 2017; 51(1):34-42.

29. Ansa BE, Coughlin SS, Alema-Mensah E, Smith SA. Evaluation of colorectal Cancer incidence trends in the United States (2000-2014). J Clin Med. 2018; 7(2):30.
30. Crosbie AB, Roche LM, Johnson LM, Pawlish KS, Paddock LE, Stroup AM. Trends in colorectal cancer incidence among younger adults-disparities by age, sex, race, ethnicity, and subsite. Cancer Med. 2018;7(8):4077-86.

31. Ellis L, Abrahao R, McKinley M, Yang J, Somsouk M, Marchand LL, Cheng I, Gomez SL, Shariff-Marco S. Colorectal Cancer incidence trends by age, stage, and racial/ethnic Group in California, 1990-2014. Cancer Epidemiol Biomark Prev. 2018;27(9):1011-8.

32. Garcia S, Pruitt SL, Singal AG, Murphy CC. Colorectal cancer incidence among Hispanics and non-Hispanic whites in the United States. Cancer Causes Control. 2018;29(11):1039-46.

33. Jacobs D, Zhu R, Luo J, Grisotti G, Heller DR, Kurbatov V, Johnson CH, Zhang $Y$, Khan SA. Defining early-onset Colon and Rectal cancers. Front Oncol. 2018;8:504.

34. Haggar FA, Preen DB, Pereira G, Holman CD, Einarsdottir K. Cancer incidence and mortality trends in Australian adolescents and young adults, 1982-2007. BMC Cancer. 2012;12:151.

35. Boyce S, Nassar N, Lee CY, Suen MK, Al Zahrani S, Gladman MA. Youngonset colorectal cancer in New South Wales: a population-based study. Erratum appears in. Med J Aust. 2016;205(10):465-70. 12;205(11):508; PMID: 27927159 .

36. Gandhi J, Davidson C, Hall C, Pearson J, Eglinton T, Wakeman C, Frizelle F. Population-based study demonstrating an increase in colorectal cancer in young patients. Br J Surg. 2017;104(8):1063-8.

37. Troeung L, Sodhi-Berry N, Martini A, Malacova E, Ee H, O'Leary P, LansdorpVogelaar I, Preen DB. Increasing incidence of colorectal Cancer in adolescents and young adults aged 15-39 years in Western Australia 19822007: examination of colonoscopy history. Front Public Health. 2017;5:179.

38. Zaridze DG, Filipchenko W. Incidence of Colo-rectal cancer in Moscow. Int J Cancer. 1990;45(3):583-5.

39. Larsen IK, Bray F. Trends in colorectal cancer incidence in Norway 19622006: an interpretation of the temporal patterns by anatomic subsite. Int J Cancer. 2010;126(3):721-32.

40. Ullah MF, Fleming CA, Mealy K. Changing trends in age and stage of colorectal cancer presentation in Ireland - from the nineties to noughties and beyond. Surgeon. 2018;16(6):350-4.

41. Nooyi SC, Murthy NS, Shivananjaiah S, Sreekantaiah P, Mathew A. Trends in rectal cancer incidence--Indian scenario. Asian Pac J Cancer Prev. 2011;12(8): 2001-6.

42. Wu QJ, Vogtmann E, Zhang W, Xie L, Yang WS, Tan YT, Gao J, Xiang YB. Cancer incidence among adolescents and young adults in urban Shanghai, 1973-2005. PLoS One. 2012;7(8):e42607.

43. Zhou Q, Li K, Lin GZ, Shen JC, Dong H, Gu YT, Liu HZ. Incidence trends and age distribution of colorectal cancer by subsite in Guangzhou, 2000-2011. Chin J Cancer. 2015;34(8):358-64.

44. Nakagawa $\mathrm{H}$, Ito H, Hosono S, Oze I, Mikami H, Hattori M, Nishino Y, Sugiyama H, Nakata K, Tanaka H. Changes in trends in colorectal cancer incidence rate by anatomic site between 1978 and 2004 in Japan. Eur J Cancer Prev. 2017;26(4):269-76.

45. Sarakarn $P$, Suwanrungruang $K$, Vatanasapt $P$, Wiangnon $S$, Promthet $S$, Jenwitheesuk K, Koonmee S, Tipsunthonsak N, Chen SL, Yen AM, et al. Joinpoint analysis trends in the incidence of colorectal Cancer in Khon Kaen, Thailand (1989 - 2012). Asian Pac J Cancer Prev. 2017;18(4):1039-43.

46. Zhang B, Xie SH, Yu IT. Differential incidence trends of colon and rectal cancers in Hong Kong: an age-period-cohort analysis. Cancer Commun. 2018:38(1):42.

47. Hamdi Cherif M, Serraino D, Mahnane A, Laouamri S, Zaidi Z, Boukharouba H, Cherka D, Rakeb M, Kara L, Ayat A, et al. Time trends of cancer incidence in Setif, Algeria, 1986-2010: an observational study. BMC Cancer. 2014;14: 637.

48. Siegel RL, Miller KD, Fedewa SA, Ahnen DJ, Meester RGS, Barzi A, Jemal A. Colorectal cancer statistics, 2017. CA Cancer J Clin. 2017;67(3):177-93.

49. Bailey CE, Hu CY, You YN, Bednarski BK, Rodriguez-Bigas MA, Skibber JM, Cantor SB, Chang GJ. Increasing disparities in the age-related incidences of colon and rectal cancers in the United States, 1975-2010. Erratum appears in. JAMA Surg. 2015;150(1):17-22 150(3):277; PMID: 25785512.

50. Siegel RL, Miller KD, Jemal A. Colorectal Cancer mortality rates in adults aged 20 to 54 years in the United States, 1970-2014. JAMA. 2017;318(6): 572-4.

51. Koblinski J, Jandova J, Nfonsam V. Disparities in incidence of early- and lateonset colorectal cancer between Hispanics and Whites: A 10-year SEER database study. Am J Surg. 2018;215(4):581-5. 
52. Ahnen DJ, Wade SW, Jones WF, Sifri R, Mendoza Silveiras J, Greenamyer J, Guiffre S, Axilbund J, Spiegel A, You YN. The increasing incidence of youngonset colorectal cancer: a call to action. Mayo Clin Proc. 2014;89(2):216-24.

53. Campos FG. Colorectal cancer in young adults: a difficult challenge. World J Gastroenterol. 2017;23(28):5041-4.

54. O'Connell JB, Maggard MA, Livingston EH, Yo CK. Colorectal cancer in the young. Am J Surg. 2004;187(3):343-8.

55. Bleyer A. CAUTION! Consider cancer: common symptoms and signs for early detection of cancer in young adults. Semin Oncol. 2009;36(3):207-12.

56. Imperiale TF, Kahi CJ, Rex DK. Lowering the Starting Age for Colorectal Cancer Screening to 45 Years: Who Will Come... and Should They? Clin Gastroenterol Hepatol. 2018;16(10):1541-4.

57. Anderson JC, Samadder JN. To screen or not to screen adults $45-49$ years of age: that is the question. Am J Gastroenterol. 2018;113(12):1750-3.

58. Abualkhair WH, Zhou M, Ahnen D, Yu Q, Wu X-C, Karlitz JJ. Trends in incidence of early-onset colorectal Cancer in the United States among those approaching screening age. JAMA Netw Open. 2020;3(1):e1920407.

59. Araujo L, Breau G, George M, Dau H, Gastonguay L, Hansn Brown E, De Vera M. Shared experiences of diagnosis and treatment of young-onset colorectal cancer: a patient-oriented qualitative study. J Psycosocial Oncol Pract. 2020; In Press.

60. Colorectal Cancer Alliance: 2018 Young-onset colorectal cancer survey. In 2019.

\section{Publisher's Note}

Springer Nature remains neutral with regard to jurisdictional claims in published maps and institutional affiliations.

Ready to submit your research? Choose BMC and benefit from:

- fast, convenient online submission

- thorough peer review by experienced researchers in your field

- rapid publication on acceptance

- support for research data, including large and complex data types

- gold Open Access which fosters wider collaboration and increased citations

- maximum visibility for your research: over $100 \mathrm{M}$ website views per year

At BMC, research is always in progress.

Learn more biomedcentral.com/submissions 